\title{
New species in the Hungarian avifauna in 2016
}

\section{Tibor HADARICS}

Received: November 05, 2017 - Accepted: December 2017

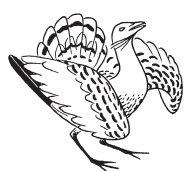

Hadarics, T. 2017. New species in the Hungarian avifauna in 2016. - Ornis Hungarica 25(2): 104-108. DOI: 10.1515/orhu-2017-0017

Abstract Two new species appeared in the Hungarian avifauna in 2016: the Rock Pipit and the Yellow-billed Loon. The Rock Pipit was trapped and ringed in the habitat reconstruction area (Borsodi-dúlö) near Fertóújlak on $10^{\text {th }}$ October. The Yellow-billed Loon was seen and photographed on the Lake Balaton at Balatonföldvár, Szántód and Zamárdi on 3-13 $3^{\text {th }}$ December. The number of bird species which occurred in Hungary has risen to 414 with the occurrences of these species.

Keywords: official bird checklist, Hungarian Checklist and Rarities Committee, Rock Pipit, Anthus petrosus, Yellow-billed Loon, Gavia adamsii

Összefoglalás 2016-ban két faunára új madárfaj bukkant fel Magyarországon: a parti pityer és a fehércsőrủ búvár. A parti pityert 2016. október 10-én fogták és gyürűzték a Fertőújlak melletti élőhely-rekonstrukciós területen (Borsodi-dủlö), a fehércsőrü búvárt pedig 2016. december 3-13. között figyelték meg és fényképezték a Balatonon, Balatonföldvár, Szántód és Zamárdi térségében. E két faj előkerülésével a Magyarországon valaha bizonyítottan előfordult madárfajok száma 414-re emelkedett.

Kulcsszavak: Magyarország madarainak névjegyzéke, MME Nomenclator Bizottság, parti pityer, Anthus petrosus, fehércsőrü búvár, Gavia adamsii

Tibor Hadarics, 9400 Sopron, Wälder József utca 4. D/2., Hungary

e-mail: sitke@upcmail.hu

In 2016, two bird species was accepted by the Hungarian Checklist and Rarities Committee as new to the Hungarian fauna. These are the Rock Pipit (Anthus petrosus) and the Yellow-billed Loon (Gavia adamsii). By these, the number of bird species found in Hungary to date has risen to 414 .

Anthus petrosus (Montagu, 1798) - Rock Pipit

$10^{\text {th }}$ October 2016, Fertőújlak, Borsodi-dülö, $1 \mathrm{imm}$. (1y) (probably male) exemplar (T. Hadarics and others)

The Rock Pipit formerly treated as conspecific with Water Pipit (A. spinoletta). The split of the two taxa into separate species is based on subtle differences in their plumage (Alström \& Mild 1987, 1996, 1997, Knox 1988), moulting (Williamson 1961) and voice, including both song and calls (Alström \& Mild 1987). The two taxa are allopatric in the Western Palearctic, their breeding areas do not overlap and they breed in completely different habitats: whereas the Rock Pipit breeds primarily on rocky sea shores, the Water Pipit is a typical mountain species. The difference in habitat use persists also during the winter period, and they occur in different habitats even in places where they both overwinter (Bijlsma 1977). 
The separation of the two taxa has also been confirmed by molecular biology methods, and the tests showed that these two taxa are phylogenetically the closest within pipits (Voelker 1999), only having separated ca. 144,000 years ago (Arctander et al. 1996). The identification of them as separate species became commonplace since the end of the 1990s/beginning of 2000s (Sangster et al. 2002, Collinson 2006), and nowadays they are described as two separate species in every checklist, identification guide and handbook.

The Rock Pipit breeds on the rocky shores of the Jylland, Scandinavian Peninsula, Finland and Kola Peninsula (ssp. littoralis), seashores of Bretagne and British Isles (ssp. petrosus), as well as on the Faroes, Orkney and Shetland (ssp. kleinschmidti) (Tyler 2004). Whereas the petrosus is mostly resident showing some dispersion and the kleinschmidti also only migrates short distances from the breeding grounds, most populations of the littoralis (except the southern ones) migrate, wintering on the rocky Atlantic coasts of Western Europe from Southern Scandinavia to Gibraltar, even in Northwestern Africa (Tyler 2004). The species is rarely seen far away from the Western European coasts, such as Central and Eastern Europe, although an occurrence is known from Greece (Vittery 2006). Because the Rock Pipit is tightly connected to the coast both during migration and overwintering, it rarely appears in Central Europe. Of the countries adjacent to Hungary, it only occurred once in Austria and once in Ukraine. In Austria, one exemplar was observed and photographed on $14^{\text {th }}$ November 2015 by the river Inn at Mining (Upper Austria) (Pumberger 2017), and in Ukraine, it was photographed on $7^{\text {th }}$ November 2016 in the coastal part of Danube Delta (Yakovlev 2016).

In Hungary, one Rock Pipit was caught with a walking trap and ringed on $10^{\text {th }}$ October 2016 at the habitat reconstruction area (Borsodi-dűlö) near Fertőújlak by Tibor Hadarics (2016). This Rock Pipit was a first year bird in first winter plumage. Based on registered biometric data (primarily the $90 \mathrm{~mm}$ wing length), the captured specimen was most probably a male, because the sex of even first-year birds can be relatively precisely determined by the wing length in the littoralis subspecies of the Rock Pipit (Larsson \& Strandvik 1986). Subspecies of the Rock Pipit (ssp. petrosus and ssp. littoralis) can be distinguished neither by the colour of the plumage nor biometric data, thus subspecies status of the captured bird could not be determined. However, because the English petrosus subspecies (Western Rock Pipit) is not a migrant, but the littoralis subspecies (Scandinavian Rock Pipit) is, the appearance of the latter in Central Europe is more probable. This was the first well documented and confirmed record of the Rock Pipit in Hungary, and the first record in the Carpathian Basin.

Gavia adamsii (G. R. Gray, 1859) - Yellow-billed Loon

3-13 ${ }^{\text {th }}$ December 2016, Balatonföldvár, Szántód and Zamárdi, Lake Balaton, 1 imm. (1y) exemplar (B. Kókay and others)

The Yellow-billed Loon breeds on the Siberian tundra from southern island of Novaya Zemlya across Northern Siberia to Chukotka Peninsula, and on the North American tundra from northern Alaska east to Melville Peninsula (Carboneras 1992). Birds that breed in North America overwinter in Southern Alaska and the Pacific coast of Canada, and those from East Siberia spend the winter in the coastal regions of Japan and the Korean Peninsula, whereas 
West Siberian breeders overwinter in Northern Europe on the northern and western shores of the Kola and Scandinavian Peninsula (Carboneras 1992). In the last decades, it was more regularly spotted on the North and Baltic Sea (Lewington et al. 1991).

The Yellow-billed Loon usually nests on freshwater lakes of the tundra, but occasionally also on the seashore or along rivers (Carboneras 1992). In the winter, it mostly stays near the seashore, whereas birds wandering inland, occur primarily on bigger lakes, rivers and reservoirs.

Because the species is strongly connected to the coastal zones of seas both during migration and overwintering, it very occasionally appears in inland Europe. Of the countries adjacent to Hungary, it occurred nine times in Austria, four times in Slovenia, and twice in Slovakia and Croatia. Its last observation in Austria was an exemplar in first winter plumage $(2 \mathrm{y})$ between $2^{\text {nd }}$ February and $7^{\text {th }}$ March 2014 (Albegger \& Khil 2016). In Slovenia, one exemplar was seen on $13^{\text {th }}$ November 1982 on the River Dragonja (Sečoveljske soline)

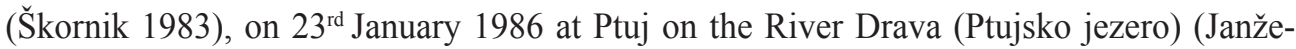

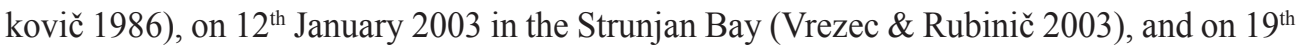
March 2004 on the sea near Sečoveljske soline (Szymański 2004). In Slovakia one specimen was shot on $25^{\text {th }}$ November 1884 on the river Orava near Istebné (Ferianc 1964), and another one was observed between $8^{\text {th }}$ January and $13^{\text {th }}$ February 1997 on the River Danube near Bratislava (Somogyi 1997). In Croatia, on $19^{\text {th }}$ December 1908 an adult female specimen was shot along the river Sava near Babina Greda (Nagy 1917), the preparatum of which is exhibited in the Croatian Natural History Museum, Zagreb (Grbac \& Kralj 2008). Another bird was observed between $1^{\text {st }}$ February and $2^{\text {nd }}$ March 2004 on the River Drava near Osijek (Kralj 2005). The Slovakian and Croatian data of the species are also Carpathian Basin occurrences.

Two observations are known from Hungary on Lake Balaton: one exemplar on 25-26 $6^{\text {th }}$ November 1977 at Balatonlelle (Fülöp 1982), and another one on 30 $0^{\text {th }}$ November 1982 at Balatonalmádi (Bankovics 1986). However, because neither photos nor detailed descriptions were made of the birds and the observers were alone at the time of the events, the observations were not accepted by the Hungarian Checklist and Rarities Committee, and thus they could not be included in the Hungarian checklist.

A first winter plumage (1y) Yellow-billed Loon was seen by Bence Kókay on $3^{\text {th }}$ December 2016 on the Lake Balaton at Balatonföldvár. The bird was observed and photographed by many birdwatchers at Szántód on the next day, and at Zamárdi on the next week until $13^{\text {th }}$ December. This was the first well documented and confirmed record of Yellow-billed Loon in Hungary, and the fifth record in the Carpathian Basin.

\section{Acknowledgements}

I would like to express my gratitude to referees and József Vuts who made the English translation of the manuscript. 


\section{References}

Albegger, E. \& Khil, L. 2016. Nachweise seltener und bemerkenswerter Vogelarten in Österreich 2012-2014. 9. Bericht der Avifaunistischen Kommission von BirdLife Österreich [Records of rare and remarkable bird species in Austria 2012-2014. Ninth report of the Avifaunistic Commission of BirdLife Austria]. - Egretta 54: 118-144. (in German with English Summary)

Arctander, P., Folmer, O. \& Fjeldså, J. 1996. The phylogenetic relationships of Berthelot's Pipit Anthus berthelotii illustrated by DNA sequence data, with remarks on the genetic distance between Rock and Water Pipits Anthus spinoletta. - Ibis 138(2): 263-272. DOI: 10.1111/j.1474-919X.1996.tb04338.x

Alström, P. \& Mild, K. 1987. Some notes on the taxonomy of the Water Pipit complex. - In: International bird identification. Proceedings of the $4^{\text {th }}$ International Identification Meeting, Eilat 1-8. November 1986. - International Birdwatching Center, Eilat, pp. 47-48.

Alström, P. \& Mild, K. 1996. The identification of Rock, Water and Buff-bellied Pipits. - Alula 2(4): 161-175.

Alström, P. \& Mild, K. 1997. Die Bestimmung des Wasserpieper-Komplexes: Berg- Anthus spinoletta, StrandA. petrosus, Pazifikpieper A. rubescens und Rosenpieper A. roseatus [The identification of the Water Pipit complex: Anthus spinoletta, A. petrosus, A. ribescens and Rosy Pipit A. roseatus]. - Limicola 11(1): 1-24. (in German with English Summary)

Bankovics, A. 1986. A Balaton átvonuló és telelő vízimadarainak állománybecslése [Estimate of the water-fowl population passing across Lake Balaton]. - Aquila 92: 58-64. (in Hungarian with English Summary)

Bijlsma, R. 1977. Voorkomen en oecologie van Anthus spinoletta spinoletta en A. s. littoralis in de uiterwaarden van de Rijn bij Wageningen [The occurrence and ecology of Anthus spinoletta spinoletta and A. s. littoralis int he forelands of the river Rhine near Wageningen]. - Limosa 50(3-4): 127-136. (in Dutch with English Summary)

Carboneras, C. 1992. White-billed Diver Gavia adamsii. - In: del Hoyo, J., Elliott, A. \& Sargatal, J. (eds.) Handbook of the birds of the World. Vol. 9. Ostrich to ducks. - Lynx Edicions, Barcelona, p. 172.

Collinson, M. 2006. Splitting headaches? Recent taxonomic changes affecting the British and Western Palearctic lists. - British Birds 99(6): 306-323.

Ferianc, O. 1964. Stavovce Slovenska II. Vtáky I. [Vertebrates of Slovakia II. Birds I.]. - Vydavatel'stvo Slovenskej Akadémie Vied, Bratislava, pp. 317-319. (in Slovakian)

Fülöp, L. Z. 1982. Fehércsőrủ búvár (Gavia adamsi) Balatonlellén [White-billed Diver (Gavia adamsi)]. - Aquila 88: 127, 133. (in Hungarian and English)

Grbac, I. \& Kralj, J. 2008. Katalog zbirke ptica Hrvatskog Prirodoslovnog Muzeja [The catalogue of the bird collection of the Croatian Natural History Museum]. - Natura Croatica 17(Suppl.1): 1-226. (in Croatian and English)

Hadarics, T. 2016. A parti pityer első előfordulása Magyarországon [First occurrence of the Rock Pipit in Hungary]. - Madártávlat 23(4): 26-27. (in Hungarian)

Janžekovič, F. 1986. Rumenokljuni slapnik Gavia adamsii [White-billed Loon Gavia adamsii]. - Acrocephalus 7(27-28): 13. (in Slovenian)

Knox, A. 1988. Taxonomy of the Rock/Water Pipit superspecies Anthus petrosus, spinoletta and rubescens. British Birds 81(5): 206-211.

Kralj, J. 2005. Rijetke vrste u Hrvatskoj. II. izvješće Hrvatske Komisije za Rijetke Vrste [Rare birds in Croatia (2 ${ }^{\text {nd }}$ report of Croatian Rarities Committee)]. - Larus 49: 37-50. (in Croatian with English Summary)

Larsson, L. \& Strandvik, P. 1986. Wing length as a character for sexing Rock Pipits Anthus spinoletta littoralis. Ringing \& Migration 7(2): 71-74. DOI: 10.1080/03078698.1986.9673883

Lewington, I., Alström, P. \& Colston, P. 1991. A field guide to the rare birds of Britain and Europe. - Domino Books, St. Helier, p. 348.

Nagy, J. 1917. A Gavia glacialis (L.) újabb és a Gavia adamsi (Gray) első előfordulása Magyarországon [The recent occurrence of Gavia glacialis (L.) and the first occurrence of the Gavia adamsi (Gray) in Hungary]. Aquila 23: 350-352, 551-552. (in Hungarian and German)

Pumberger, T. 2017. Erstnachweis des Strandpiepers Anthus petrosus für Österreich [First occurrence of Rock Pipit Anthus petrosus in Austria]. - Elanus 10: 84-85. (in German)

Sangster, G., Knox, A. G., Helbig, A. J. \& Parkin, D. T. 2002. Taxonomic recommendations for European birds. - Ibis 144(1): 153-159. DOI: 10.1046/j.0019-1019.2001.00026.x

Škornik, I. 1983. Rumenokljuni slapnik Gavia adamsii [White-billed Diver]. - Acrocephalus 4(15): 15. (in Slovenian) 
Somogyi, J. 1997. Ein Gelbschnabeltaucher (Gavia adamsii) überwintert in Bratislava [A Yellow-billed Loon (Gavia adamsii) overwintered in Bratislava]. - Tichodroma 10: 190. (in German with Slovakian Summary) Szymański, M. 2004. Rumenokljuni slapnik Gavia adamsii \& Beloliska Melanitta fusca [Yellow-billed Diver \& Velvet Scoter]. - Acrocephalus 25(122): 161. (in Slovenian with English Summary)

Tyler, S. J. 2004. Rock Pipit Anthus petrosus. - In: del Hoyo, J., Elliott, A. \& Christie, D. (eds.) Handbook of the birds of the World. Vol. 9. Cotingas to pipits and wagtails. - Lynx Edicions, Barcelona, pp. 766-767.

Vittery, A. 2006. The first 'Caucasian' Water Pipits Anthus spinoletta coutellii and Rock Pipit Anthus petrosus in Greece. - Sandgrouse 28(1): 78-80.

Voelker, G. 1999. Molecular evolutionary relationships in the avian genus Anthus (Pipits: Motacillidae). - Molecular Phylogenetics and Evolution 11(1): 84-94. DOI: 10.1006/mpev.1998.0555

Vrezec, A. \& Rubinič, B. 2003. Rumenokljuni slapnik Gavia adamsii [Yellow-billed Loon]. - Acrocephalus 24(118): 109. (in Slovenian with English Summary)

Williamson, K. 1961. Moult and its relation to taxonomy in Rock and Water Pipits. - British Birds 58: 493-504.

Yakovlev, M. V. 2016. Beregovyi shchevryk (Anthus petrosus) - novyi vyd dlia fauny Ukrainy [Rock Pipit (Anthus petrosus) is a new species in the fauna of Ukraine]. - Berkut 25(2): 93-95. (in Ukrainian with English Summary)

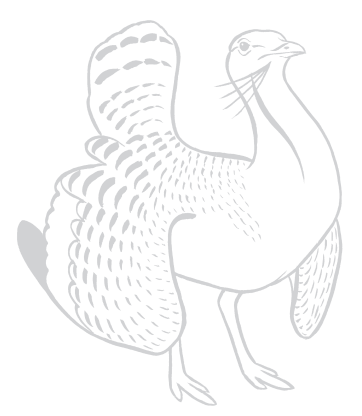

